\title{
Belt and Road Initiative and Islamic Financing: The Case in Public Private Partnership Infrastructure Financing
}

\section{JinZi Chu}

\section{Aishath Muneeza}

\section{International Centre for Education in Islamic Finance (INCEIF), Malaysia}

\begin{abstract}
China's One Belt and One Road (OBOR) is a global trade network across Asia, Africa, Europe and Oceania. Also known as Belt and Road Initiative (BRI), OBOR is an attempt to redraw ancient Silk Road to foster global trade and economic development. Nearly 30 Muslims-majority countries are part of China's vision of BRI. The purpose of this paper is twofold: first, to investigate how public private partnership (PPP) has been applied in BRI projects; and second, to explore how Islamic finance can fit within a PPP context. This paper proposes a framework for using Islamic finance in infrastructure PPP projects. This paper also analyses two PPP projects where Islamic finance was deployed as project financing. It is hoped that the discussed risks and outcome of the study will assist in integration of Islamic finance in infrastructure projects that will create efficiency in processes in cross-border cooperation.
\end{abstract}

Keywords: Belt and Road Initiative; One Belt and One Road; Public-Private Partnership; Islamic Finance; Islamic Banking 


\section{Introduction}

In September and October 2013, Chinese President Xi Jinping proposed the Belt and Road Initiative (BRI). This initiative consists of two main components: the Silk Road Economic Belt and 21st Century Maritime Silk Road. This is considered as a development strategy and framework to foster global economic and trade integration. Leading by China's government, BRI has ambition to improve regional cooperation and connectivity on a trans-continental scale, meanwhile strengthen infrastructure, trade, and investment linkages. The majority of the project investments fall under infrastructure sectors.

Spanning continents on road and maritime routs, the BRI connect more than sixty countries. According to the Islamic Corporation for The Development of the Private Sector (ICD) (2017), nearly $40 \%$ of the countries along the route are predominantly Muslims populated (see Figure 1). The BRI initially spans 65 countries, but more might be added as the initiative expanded.

Figure 1: Countries along the route of BRI

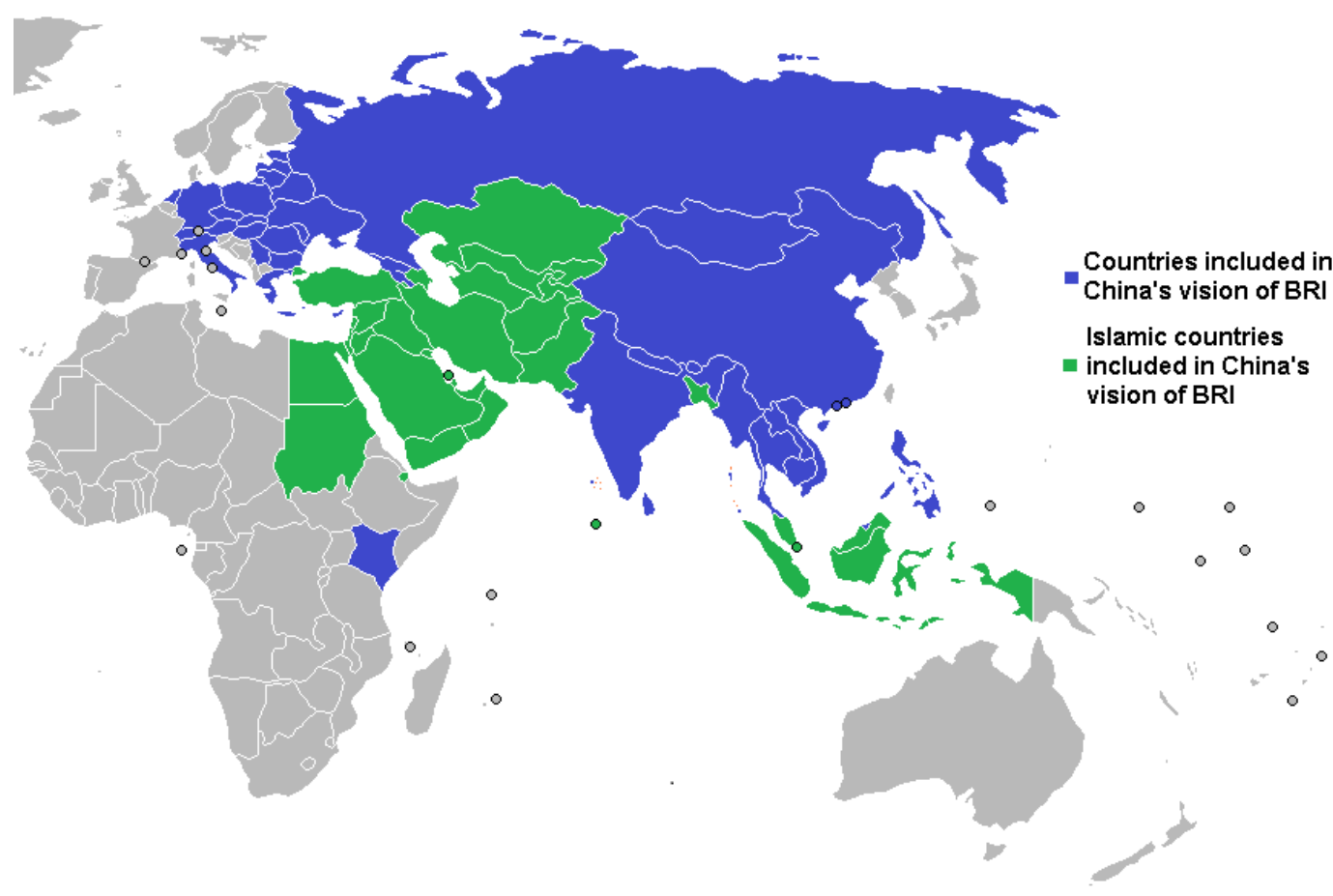

Source: Deloitte, 2018; ICD, 2017; PwC, 2017

Moreover, the Islamic economics has the potential to contribute immensely to China's economic development by supporting China's role as a 'megatrader' (Kamel, 2018). Dated back in the eight century, the Silk Road not only represents as a network of international trade routes (Selmier, 2018) but also serve as intercultural hub which allowed the travelers and merchants to exchange cultures, language, and technical know-how (Tan, 2018). Given the geopolitical and economic significance of the new

International Journal of Management and Applied Research, Vol. 6, No. 1 
Silk Road, over 100 countries and international organizations have signed cooperative documents with China, committing to participate in the BRI initiative (Tan, 2018).

The high capital intensity of BRI projects calls for innovative financing mechanism that could lead to win-win scenarios. To promote economic cooperation and infrastructure construction of countries along the BRI, China has allocated considerable financial resources, which include Silk Road Fund and Asia Infrastructure Investment Bank (AIIB). AIIB is a multilateral development bank that aims to finance infrastructure and capital projects in Asia and beyond. Muslimsmajority countries like Pakistan and Bangladesh have been the key BRI beneficiaries: AIIB approved a US\$165 million loan to Bangladesh for the distribution system upgrade and expansion project in 2016 (AIIB, 2018) and over US\$50 billion will be invested in the China-Pakistan Economic Corridor (Deloitte, 2018). Moreover, nearly all Middle East countries are members of the AIIB (AIIB, 2018) while the Silk Road Fund is in the process of initiating new joint ventures in the Middle East (Kamel, 2018). Collectively, these Muslims-majority countries occupy a strategic position along the BRI routes (Kamel, 2018), and thus having a good relationship with the Islamic countries is critical for the successful implementation of the BRI for China ( $\mathrm{Li}$, 2018).

This paper analyses the principles of Islamic Finance contracts used in infrastructure financing and the theoretical basis of the infrastructure PPP model found that Islamic finance can be well integrated together in mega infrastructure project.

This paper is structured as follows: section two presents a literature review on the need for PPP in infrastructure development, China and Islamic Finance, and also the use of Islamic financing in BRI. Section three discusses PPP model and Islamic Finance, together with two Shariah-compliant cases with the use of secondary data sources. Section four proposes a Shariah-compliant PPP model. Section five discusses common risks involved in multilateral banking infrastructure PPP business. Section six concludes the implications of Islamic financing in BRI and PPP.

\section{Literature Review}

\subsection{The Need of PPP model in Infrastructure Development}

The need for infrastructure development has been well documented; studies have shown the positive impact of infrastructure investment from economic perspective (e.g. OECD, 2017; Woetzel et al. 2016; World Bank, 2017; Zen, 2018). The infrastructure investments are highly sensitive to growth rates since economic activity not only influence demand on infrastructure assets but also generate financial resources to build them (Woetzel et al. 2016). For developing countries, poor infrastructure is an obstacle to economic growth and regional development. OECD (2017) estimates global infrastructure investment needs of US\$6.3 trillion per year over the period of 2016 and 2030 to support growing population needs and economic development. The majority of infrastructure investments will be required in emerging economies, especially China. World Bank (2017: 9) estimates that China and other emerging countries will account for 60 percent of the global infrastructure need from 2016 to 2030 .

International Journal of Management and Applied Research, Vol. 6, No. 1 
However, current spending on infrastructure has not been sufficient to meet the growing population needs (OECD, 2017; Woetzel et al. 2016; World Bank, 2017). A shortage of public funding is often cited as one of the main reasons that lead to infrastructure gap - the difference between estimated infrastructure needs and current spending commitments on infrastructure (OECD, 2017; Woetzel et al. 2016; World Bank, 2017). Developing countries face challenges such as lack of sufficient skills and resources to transform infrastructure projects into bankable projects (Woetzel et al. 2016). Chen (2016) points out that the decline in oil revenue and international oil price will impact on the scale of infrastructure construction in Saudi Arabia. In the past, Saudi government has been able to fund their infrastructure needs without support from the private sector; however, given the declining oil reserves, PPP represents a viable option for the government to meet infrastructure needs.

PPP is a contractual arrangement which allows the public sector to share responsibilities (designing, constructing, financing, operating or maintaining the asset) with the private sector. For the government, one of the most attractive aspects of PPP mode is the ability to distribute the cost of projects over a longer timeframe than traditional procurement options. If planned and managed properly, PPP can be a useful means not only address financial constraint, but also optimise resources, improve service quality and operational efficiency. According to Woetzel et al. (2016), PPP accounts for a substantial share of infrastructure investment in some developing countries.

The extensive involvement of Chinese government agencies demonstrates that the Chinese government is making a concerted effort to support PPP projects. To facilitate PPP programmes, the Ministry of Finance (MOF) has established China Public Private Partnerships Centre (CPPPC), which aims to conduct policy research, promote international exchanges, as well as provide consultancy and training related to PPP. The National Development and Reform Commission (NDRC) of China and United Nations Economic Commission for Europe (UNECE) have launched a comprehensive PPP capacity-building programme involving countries in the UNECE region and participating in the BRI (UNECE, 2017). Since 2014, a number of regulatory framework related to PPP have been introduced in order to enhance supervision and administration of PPP projects; these includes: 1) MOF issued Notice on Regulating PPP Contract Management on December 2014; 2) MOF issued Guidance on Financial Affordability Assessment of PPP Projects on April 2015; 3) NDRC and the China Securities Regulatory Commission (CSRC) jointly issued the Notice on Relevant Work of Promoting the Asset Securitisation of PPP Projects in the Traditional Infrastructures Field on December 2016 (World Bank, 2018).

PPP certainly has the potential of turning the underdeveloped BRI region into a new vibrant economic pillar and contributing to economic policy thinking by incorporating successful experiences of emerging market economies (Huang, 2016). According to China PPP Industry Development Report (2017-2018), as of April 2017, there were more than 800 PPP projects along the BRI, with a total investment of more than US\$500 billion (Central University of Finance and Economics, 2018). These projects range from energy, housing, telecommunication to transportation, which exemplify the breadth and diversity of the infrastructure Chinese government support.

International Journal of Management and Applied Research, Vol. 6, No. 1 


\subsection{China and Islamic finance}

Islamic finance receives growing interest, even in non-Muslim countries. In reference to World Bank (2017: 20): "the inherent structure of the Islamic banking system and its link to the real economy makes it a stable financing system". International Monetary Fund (2010) concluded that Islamic banks showed stronger resilience during financial crisis. Although Islamic finance is based on Islamic principles, its application is not limited to Muslims alone (ICD, 2017: 61).

One of the key features of Islamic finance is the prohibition of interest (riba), uncertainty (gharar), and speculation (maysir). Additionally, Islam encourages investors to act as partners sharing profit and risks, as opposed to the role of investors as creditors in conventional banking system. Under Islamic law, all financial contracts should be backed by assets to ensure a close link between the real economy and the financial industry (Mohieldin, 2012). Lending or borrowing with interest payments is forbidden under Islamic law. Islamic financial system is asset-backed, meaning that money must be made from tangible, physical assets, either through sale or lease modes of financing such as murabaha, ijara, salam, istisna and sukuk (Chapra, 2011).

Five commonly used Shariah-compliant financing structures are presented in Table 1. These financing structures can be used in combination or stand alone.

Table 1: Some of the commonly used Shariah-compliant financing contracts

\begin{tabular}{|c|c|c|c|}
\hline $\begin{array}{l}\text { Islamic } \\
\text { Contract }\end{array}$ & Definition & Contract type & Field \\
\hline Murabahah & $\begin{array}{l}\text { Sale of an asset or commodity with } \\
\text { an agreed profit margin on the cost } \\
\text { price }\end{array}$ & Debt-based & $\begin{array}{l}\text { Trade finance; } \\
\text { Interbank lending }\end{array}$ \\
\hline Mudarabah & $\begin{array}{l}\text { Partnership financing method in } \\
\text { which all parties jointly contribute } \\
\text { and bear losses on a contractually } \\
\text { pre-agreed basis }\end{array}$ & $\begin{array}{l}\text { Partnership- } \\
\text { based }\end{array}$ & $\begin{array}{l}\text { Venture capital funding; } \\
\text { Short-term financing }\end{array}$ \\
\hline Ijarah & $\begin{array}{l}\text { A lease for a specific rent for a } \\
\text { specific period }\end{array}$ & Leasing-based & $\begin{array}{l}\text { Financing fixed assets } \\
\text { and capital equipment }\end{array}$ \\
\hline Istisna & $\begin{array}{l}\text { Manufacture or build assets based on } \\
\text { terms specified by the buyer, at } \\
\text { agreed price, within a certain time }\end{array}$ & Debt-based & $\begin{array}{l}\text { Project financing; } \\
\text { Asset financing }\end{array}$ \\
\hline Wakalah & $\begin{array}{l}\text { Agency contract whereby a principal } \\
\text { appoints an agent to perform an act } \\
\text { or task on its behalf }\end{array}$ & Service-based & $\begin{array}{l}\text { Trade transaction; } \\
\text { Letter of Credit }\end{array}$ \\
\hline
\end{tabular}

In the light of ongoing development of bilateral economic and trade cooperation between the Islamic World and China, banking and financial cooperation opportunities will continue to increase (Chen, 2016). Many conventional financial institutions in China started to engage in Islamic financial transactions: for example, Chongqingbased Southwest Security signed an agreement with Qatar National Bank (QNB) and Qatar International Islamic Bank (QIIB) in 2015 to develop Shariah-compliant finance

International Journal of Management and Applied Research, Vol. 6, No. 1 
products (ICD, 2017). Rakhmat (2019) reported that since the launch of the BRI in 2013, Chinese banks have made efforts to establish outbound Islamic financing frameworks and the examples he has cited include the co-operation between AIIB with Islamic Development Bank (IDB) to provide infrastructure financing facilities to Islamic countries.

However, the Chinese government is taking a rather conservative attitude toward Islamic finance. Although People's Bank of China became an associate member of Islamic Financial Services Board (IFSB) in 2009, there has been limited follow up efforts on amendments from the Chinese government (Rakhmat, 2019). According to ICD (2017: 49), "the Chinese government has not implemented any specific laws promoting the development of Islamic finance or a sukuk market, which is a necessary prerequisite for the industry to grow". Although developing Islamic capital market alone may not necessarily lead to a liquid market in an absence of supportive ecosystem, the issuance of Islamic bonds (or 'Sukuk') could help mobilise large pools of assets across the Islamic world. Over the past few decades, sukuk has emerged as an alternative to conventional debt financing for capital and infrastructure projects due to its asset-backed nature and long-term stable performance (World Bank, 2017). Liberty Power in Pakistan (World Bank, 2017: 47-48) and Beijing Enterprises Water Group Ltd (Kana, 2017) are exemplars here.

In past few years, there have been a number of Chinese companies seek access to investors from the Muslim world. In 2015, Country Garden, a Guangdong-based property developer issued a Ringgit Malaysia (RM) 1.5 billion sukuk through its Malaysian subsidiary (ICD, 2017). Two years later, a subsidiary of Beijing Enterprises Water Group Ltd issued RM400 million sukuk to finance its water treatment project in Malaysia (Kana, 2017). Hao (2018) reported that four of China's largest banks (ICBC, Agricultural Bank of China, China Construction Bank and Bank of China) have entered the Dubai International Financial Centre.

Home to the Muslim Hui ethnic group in China, Ningxia Hui autonomous region is located at a geostrategic position on the Silk Road Economic Belt, connecting China to the Middle East. In 2009, Ningxia Bank launched a pilot project for Islamic finance offering Islamic banking for the local residents and businesses; however, Wang (2013) reported that there has been a lack of interest and low awareness among the Chinese Muslims and perhaps more worryingly, it may shut down.

\subsection{Islamic Financing in BRI}

The BRI strategies aimed at stimulating development and improving links with countries along its geographic periphery. The way the BRI is financed could be the most influential factor in terms of successful implementation of such transcontinental project. It is therefore crucial to explore alternative financing mechanisms such as Islamic finance. Selmier (2018) suggested that Islamic financing could provide China with a financing facility that is tailored for investment requirements and operational needs. To bridge the funding gaps on many infrastructure projects, it has been seen that China does welcome investment support from Islamic finance, as shown in the case of Tharparkar $660 \mathrm{MW}$ coal-fired project in Pakistan, where some of the financing comes from Islamic financial institutes (Dawn, 2015).

International Journal of Management and Applied Research, Vol. 6, No. 1 
Multilateral financial institutes such as the World Bank and Islamic Development Bank have discussed the flexibility of Islamic financing and its uses in project financing. World Bank (2017) illustrated how Shariah-compliant financial arrangements could fit within a PPP context, suggest that applying Islamic finance to infrastructure projects is a natural fit because "it serves the very purpose of assetbacked redistribution" (World Bank, 2017: 22). The long-term nature of most infrastructure projects allow for long-term stable rates of return to finance providers, along with a degree of risk sharing. Islamic finance is equity-based, asset-backed, and socially-responsible finance, traits associated with infrastructure projects. It also promotes risk sharing and social welfare. As such, Islamic financing would be a viable option to fund infrastructure projects for many regional governments in order to avoid debt trap.

As China continues to expand its economic influence in Muslim-majority countries, it helps to understand the merits associated with Islamic finance and employ those merits in development policies. Selmier (2018) suggested three ways to integrate Islamic economics into the BRI: 1) utilise Islamic financial products that fit into BRI's financing strategy; 2) use Islamic financing centres which follow less restrictive standards; and 3) expand AIIB ties with Islamic finance experts. As ICD (2017: 87) put it: "collaborations between mature and emerging regional centres in Islamic finance can serve as a catalyst for the development of talent and knowledge in the industry".

\section{PPP model and Islamic Finance}

\subsection{The concept and general structure of PPP}

Initially developed by the United Kingdom government in the 1990s, public-private partnership (PPP) became globally known both as an alternative procurement option for the public sector and a viable investment opportunity for private investors (Bing et al., 2005). Despite of its popularity, there is no universally accepted definition of PPP. The PPP Knowledge Lab (2017) defines a PPP as "a long-term contract between a private party and a government entity, for providing a public asset or service, in which the private party bears significant risk and management responsibility, and remuneration is linked to performance". In practice, however, PPP policy is defined and implemented differently. Colombia's National PPP Law, for instance, specified that the private investor is responsible for operations and maintenance for all PPP contracts, and must not exceed 30 years timeframe (PPP Knowledge Lab, 2017). The implementation of PPP policy also varies by countries. Indonesia, for instance, has more than one institution responsible for coordinating PPP projects where as countries like Malaysia, Vietnam, and Thailand, established a dedicated unit acts as a one-stop service to manage PPP projects was set up (Zen, 2018).

In most PPP contracts, a project company is formed carry out a specific business operation for a finite period of time, often known as Special Purpose Vehicle (SPV). This separate legal entity raises fund through a combination of equity (provided by project sponsor), loan (typically provided by banks), bonds, or other financial

International Journal of Management and Applied Research, Vol. 6, No. 1 
instruments (PPP Knowledge Lab, 2017). Debt funds account for $70 \%$ or more of the total assets of the PPP project company. Most of the debt financing is through bank loans (including syndicated loans) and bond issuance. In addition to that, trust fund, insurance fund, and pension fund have also been used in PPP project financing. Before commencing any PPP project, governments need to ensure that the project design is bankable-that is, the project "can attract not only equity finance from its shareholders, but also the required amount of debt" (PPP Knowledge Lab, 2017: 45). Furthermore, the operating cash flows need to be sufficient to cover underlying cost of funds to the lender plus a fixed component (or "margin"). Figure 2 illustrates a typical financial structure of a PPP project.

Figure 2: Flow of Funds in a PPP project

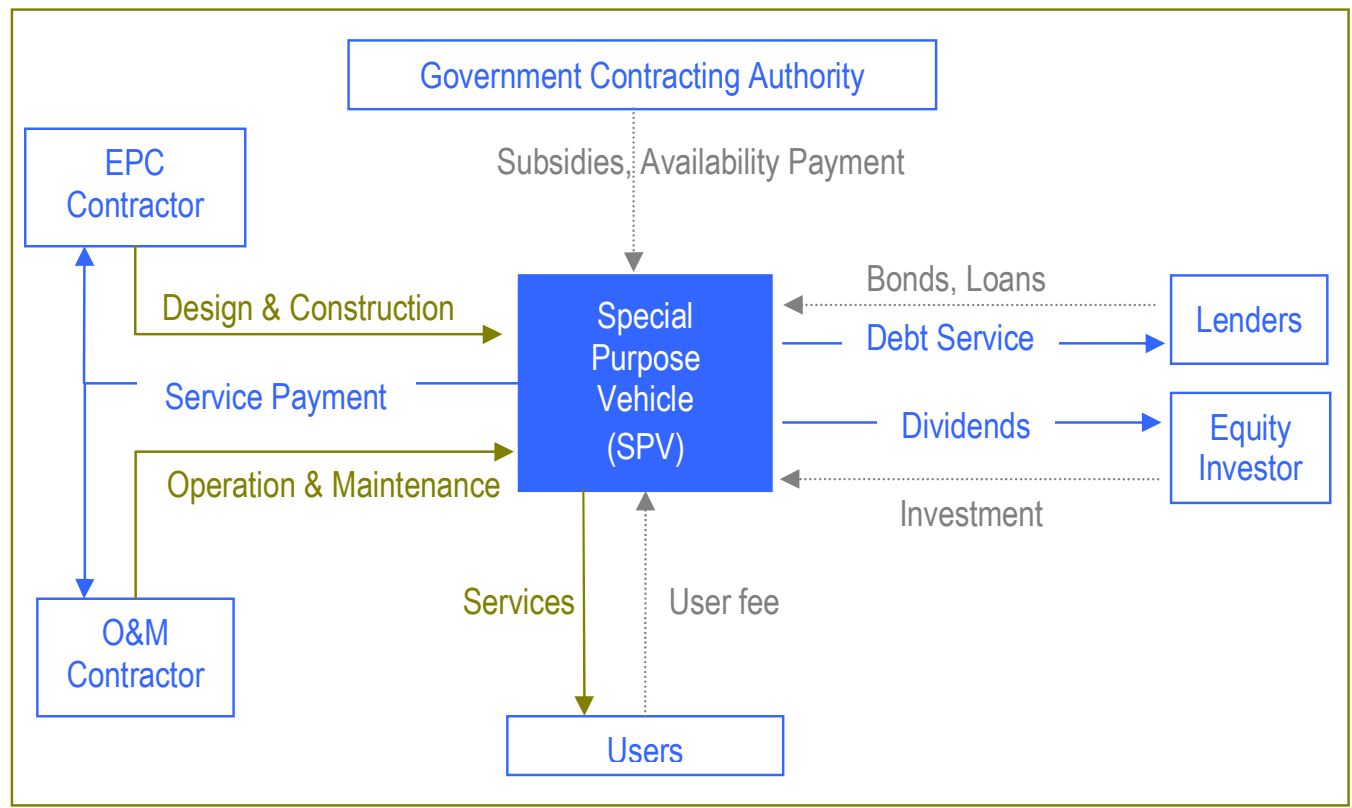

Source: PPP Knowledge Lab (2017: 42)

To begin with, the government (the procuring authority) contracts with a private agent for design and build a new (or upgraded) infrastructure. After awarding the contract, a Special Purpose Vehicle (SPV) is formed, which oversee the entire project and enter contracts with Engineering, Procurement and Construction (EPC) contractors, and Operation and Maintenance $(\mathrm{O} \& \mathrm{M})$ contracts with the O\&M contractors. Governments may fund PPP project in the form of grant, subsidy, equity, debt, or guarantee (PPP Knowledge Lab, 2017).

SPV pays to contractors and suppliers based on mutual financial agreements, which may be fixed amount or variable rate (in some O\&M contracts). In some projects, EPC contractors receive advanced payment while in some cases contractors receive payment at completion of construction.

SPV does not receive payment until the facility is available for use. The revenue regimes in PPP projects include user fee and government payment. Revenues received

International Journal of Management and Applied Research, Vol. 6, No. 1 
from the provision of service (e.g. water, sanitation, transport) are apportioned between operating revenues and capital repayment (to investors and lenders). Debt service refers to required payment to borrowings, where SPV repays its creditors or lenders. Equity investors receive dividends in return, which come into place later stage of the contract.

Alongside conventional financing mechanism, Islamic finance has emerged as an alternative financing in PPP projects, especially in Muslims-majority countries like Turkey and Saudi Arabia. Istisna (procurement) and ijarah (leasing) are commonly used in project financing. During construction and development stage, ijarah is signed between Islamic financier and SPV, where SPV is commissioned to design and construct the infrastructure. Following to that, both parties may enter ijarah contract whereby the Islamic financier grant the same project asset to the SPV (PPP Knowledge Lab, 2017; World Bank, 2017).

\subsection{PPP projects along the BRI route}

Infrastructure investment along the BRI routes will continue to grow and the use of PPP has been increased to address the infrastructure gap. BRI projects are typically backed by the Chinese state as well as the host governments along the BRI routes (Deloitte, 2018). Investors participate in project finance by partnering with stateowned enterprises and establishing joint financing with multilateral financial institutions such as Asian Infrastructure Investment Bank and Asian Development Bank. In addition to providing cross-border debt financing for the BRI projects, the joint ventures or partnerships also responsible for operation and maintenance. Table 2 presents selected PPP projects along the BRI routes.

Table 2: Selected BRI PPP Projects

\begin{tabular}{lllr}
\hline Country & Project name & Financing & Source \\
\hline Bangladesh & $\begin{array}{l}\text { Payra Thermal Power } \\
\text { Plant Project }\end{array}$ & $\begin{array}{l}\text { 70\% of debt provided through loan } \\
\text { from Chinese banks, led by Export- } \\
\text { Import Bank of China (Exim) }\end{array}$ & Compelo, 2018 \\
Cambodia & Kemchay Dam & $\begin{array}{l}\text { Part of a aid package to Cambodia; } \\
\text { loan provided by China Exim Bank }\end{array}$ & $\begin{array}{r}\text { International } \\
\text { Rivers, 2012 }\end{array}$ \\
Cambodia & $\begin{array}{l}\text { Lower Sesan II } \\
\text { Hydropower Plant }\end{array}$ & $\begin{array}{l}70 \% \text { of the project was funded by an } \\
\text { undisclosed bank loan }\end{array}$ & BankTrack, \\
Ethiopia, & $\begin{array}{l}\text { Ethiopia-Djibouti } \\
\text { Djibouti }\end{array}$ & $\begin{array}{l}\text { 7tandard Gauge Rail } \\
\text { a loan from the China Exim Bank }\end{array}$ & Maasho, 2018 \\
Pakistan & $\begin{array}{l}\text { Pakistan Sachal Wind } \\
\text { Power Project }\end{array}$ & $\begin{array}{l}85 \% \text { loan provided by Industrial and } \\
\text { Commercial Bank of China }\end{array}$ & Yang, 2018 \\
Pakistan & $\begin{array}{l}\text { Port Qasim Power } \\
\text { Plant }\end{array}$ & $\begin{array}{l}75 \% \text { loan provided by China Exim } \\
\text { Bank }\end{array}$ & PwC, 2017 \\
Sri Lanka & $\begin{array}{l}\text { Mattala Rajapaksa } \\
\text { International Airport }\end{array}$ & $\begin{array}{l}\text { More than 90\% of total costs come in } \\
\text { the form of loan provided by China } \\
\text { Exim Bank }\end{array}$ & Shepard, 2016 \\
& & &
\end{tabular}

International Journal of Management and Applied Research, Vol. 6, No. 1 
As shown in Table 4, majority of host countries take loans through state-funded Chinese banks. Unless future project returns will be sufficient to fully cover repayments to Chinese creditors, these PPP projects will add financial burden to the host countries, leaving them vulnerable to financial distress. This led countries like Bangladesh, Malaysia and Myanmar backed away from previous negotiation (Chandran, 2019).

Risks associated with the BRI projects can be broadly divided into three types: funding, geopolitical, and operational (PwC, 2017). Geopolitical dynamics play a central role in multinational project like BRI; all participating countries and companies could face challenges such as corruption (Deloitte, 2018), unstable political regimes within host countries, and likelihood of cross-territorial disputes (PwC, 2017). The Hambantota Port in Sri Lanka (Deloitte, 2018) as well as Kashmir between Pakistan and India $(\mathrm{PwC}, 2017)$ are examples of how regional political concerns could influence the successful implementation of infrastructure projects. Additionally, infrastructure project at transcontinental scale like BRI face operational challenge such as lack of central coordination mechanism (Huang, 2016). The inconsistency in regulatory regimes, volatility of exchange rates, underdeveloped credit markets, differences in trading terms further exacerbate the operational challenges in BRI projects ( $\mathrm{PwC}$, 2017). Many of these obstacles lead to risks of cost overrun and time delay of the projects.

\subsection{Case studies}

Given the background information on Islamic finance and PPP, we can now examine two cases, delving further into Islamic finance by seeing how the principles manifest in each project. Within this sample, Saudi Arabia is a medium-sized, high-income country in population terms, with considerable energy resources and seaport facilities. Turkey has a large, comparatively lower income population, and the country has fewer oil fields than its oil-rich neighbours. The Konya Integrated Health Campus in Turkey is financed by a combination of conventional lenders and Islamic financiers. The expansion of Madinah Airport in Saudi Arabia is another example of how Islamic finance can be structured innovatively to finance infrastructure project.

\subsubsection{Case 1: Shariah Turkey Konya Integrated Health Campus}

Turkey Konya Integrated Health Campus is the healthcare PPP project financed by the Islamic Development Bank (IsDB) in Turkey (Bilen, 2017). It is also the first hybrid project financed by both conventional financing and Islamic financing under a dualtranche structure. Rana (2015) addressed the concept known as "common security pool" where the Islamic banks undertake to put their ownership right of an asset in favour of common security pool in a default scenario. Conventional and Islamic financer is shared pari-passu in co-financing (PPP Knowledge Lab, 2017: 44).

In the construction phase, Istisna was used for advance funding for the project, where parallel lenders participated. SPV repays to the Islamic financier on a deferred payment basis, which is made in instalment and synchronized to the SPV's repayment

International Journal of Management and Applied Research, Vol. 6, No. 1 
of the loan to the conventional lenders (World Bank, 2017). The SPV enters into a combination of procurement and agency arrangements with financiers to subcontract its obligations (design, engineer, procure, construct, and deliver project assets) to EPC contractors. The financing structure of this project is shown in the Figure 3.

Figure 3: Turkey Konya Integrated Health Campus PPP

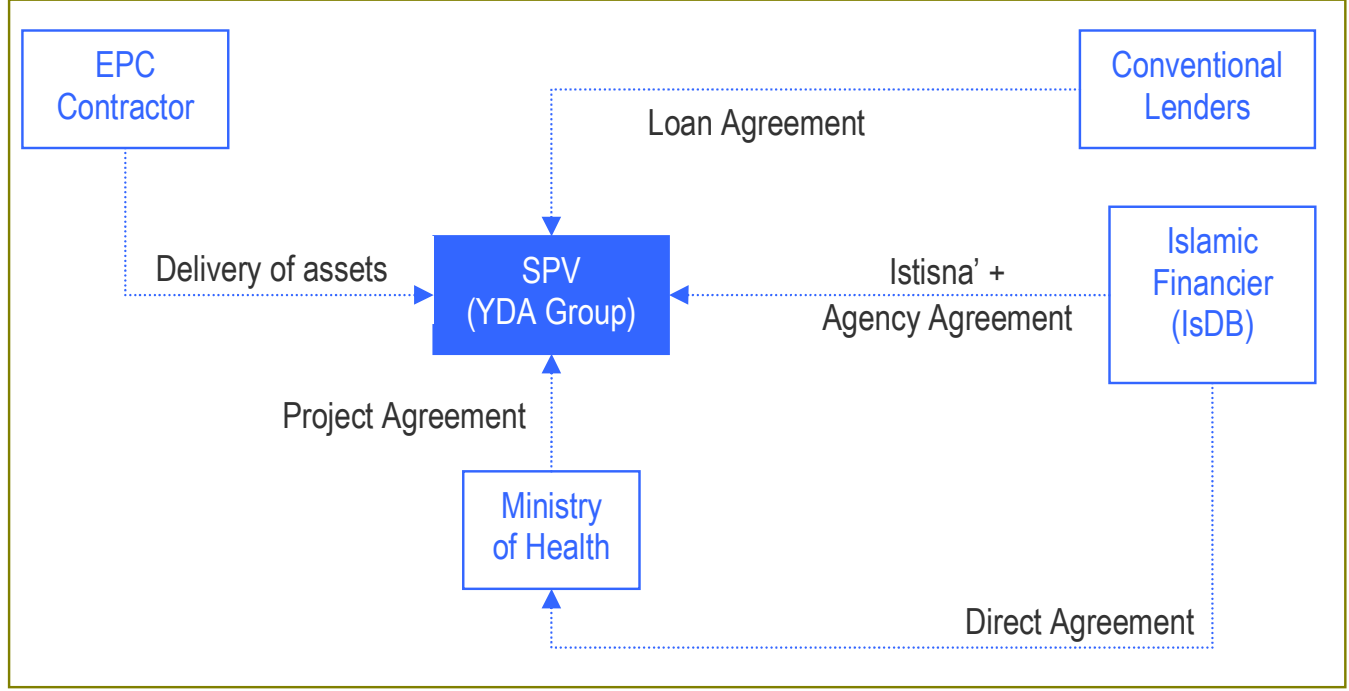

Source: World Bank (2017: 46)

\subsubsection{Case 2: Expansion of Madinah Airport in Saudi Arabia}

The expansion of Madinah Airport in Saudi Arabia was the first international airport in the world where the project was financed entirely on an Islamic basis under a PPP scheme (Global Islamic Finance Report, 2016). Two Islamic finance instruments were used to finance this project, in two consecutive stages: first, during the construction stage, the Islamic financiers used istisna to fund the project; second, during the operation stage, the Islamic financiers transfer the ownership of asset to the SPV through a lease agreement (ijarah). Figure 4 illustrates the finance structure of the project.

The monthly lease payments during the PPP project operation phase is calculated based on the total cost of the fund plus the profit. World Bank (2017) indicates that many Islamic financiers still prefer not to take on direct exposure to construction risks, and follow an ijarah-only structure. Ijarah is a financial product that can provide Islamic funders with a fixed income. It is for this reason that istisna and ijarah are commonly used together for long term financing arrangements. Istisna contract provides PPP project assets to Islamic funders, and ijarah contract ensures that PPP project assets can generate income (repayment of loan amounts) for Islamic funders through the operation of the lease.

International Journal of Management and Applied Research, Vol. 6, No. 1 
Belt and Road Initiative and Islamic Financing: The Case in Public Private Partnership Infrastructure Financing

Figure 4: Islamic Finance Structure of Madinah PPP Airport Project

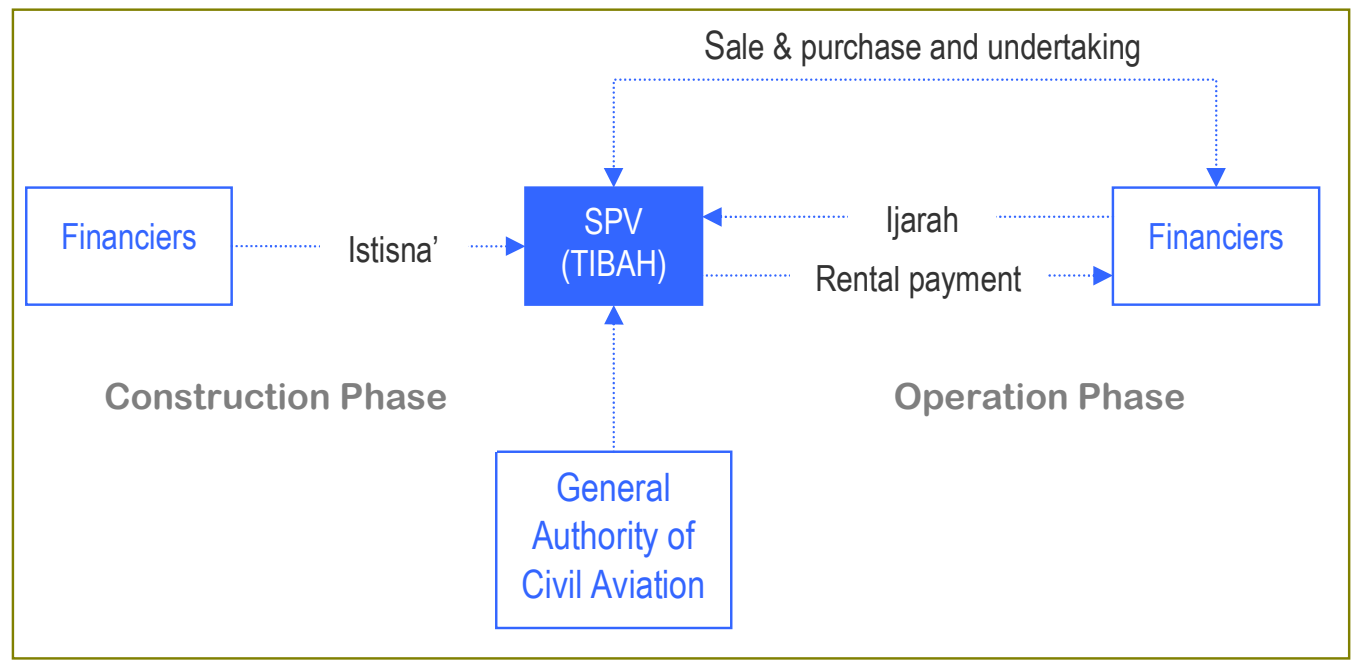

Source: World Bank (2017: 49)

These two Shariah compliant PPP cases show that Islamic and conventional financing could coexist on an equal footing basis in the same infrastructure project. These cases also demonstrate the flexibility of Islamic finance structures to accommodate varied infrastructure needs and finance PPP projects.

\section{A proposed structure}

By its very nature, infrastructure project is capital intensive, and multiple sources of financing are often required. Given the significant liquidity in most Islamic financial institutes, the asset-linked and long-term natures of PPPs make them a good investment opportunity for Islamic banking (World Bank, 2017). Konya Integrated Health Campus in Turkey shows that conventional and Islamic financing could be used in conjunction as project financing. The expansion of Madinah Airport in Saudi Arabia, on the other hand, demonstrates that procurement (istisna) and lease (ijarah) can be combined in financing infrastructure project.

According to World Bank (2017), one of the key features of Islamic finance is the flexibility of Shariah structures to accommodate infrastructure needs that are specific to the country, sector, and project, thus allowing Islamic finance providers to craft the most appropriate solution. Islamic finance can offer complementary sources of financing, considering the dearth of financing to bridge the infrastructure gap.

Figure 5 illustrates a proposed PPP model which integrates conventional and Islamic institutions together based on the proportionate of investment contribution. The contracts used in this proposed shall be all Shariah compliant.

International Journal of Management and Applied Research, Vol. 6, No. 1 
Belt and Road Initiative and Islamic Financing: The Case in Public Private Partnership Infrastructure Financing

Figure 5: Illustration on proposed PPP infrastructure structure

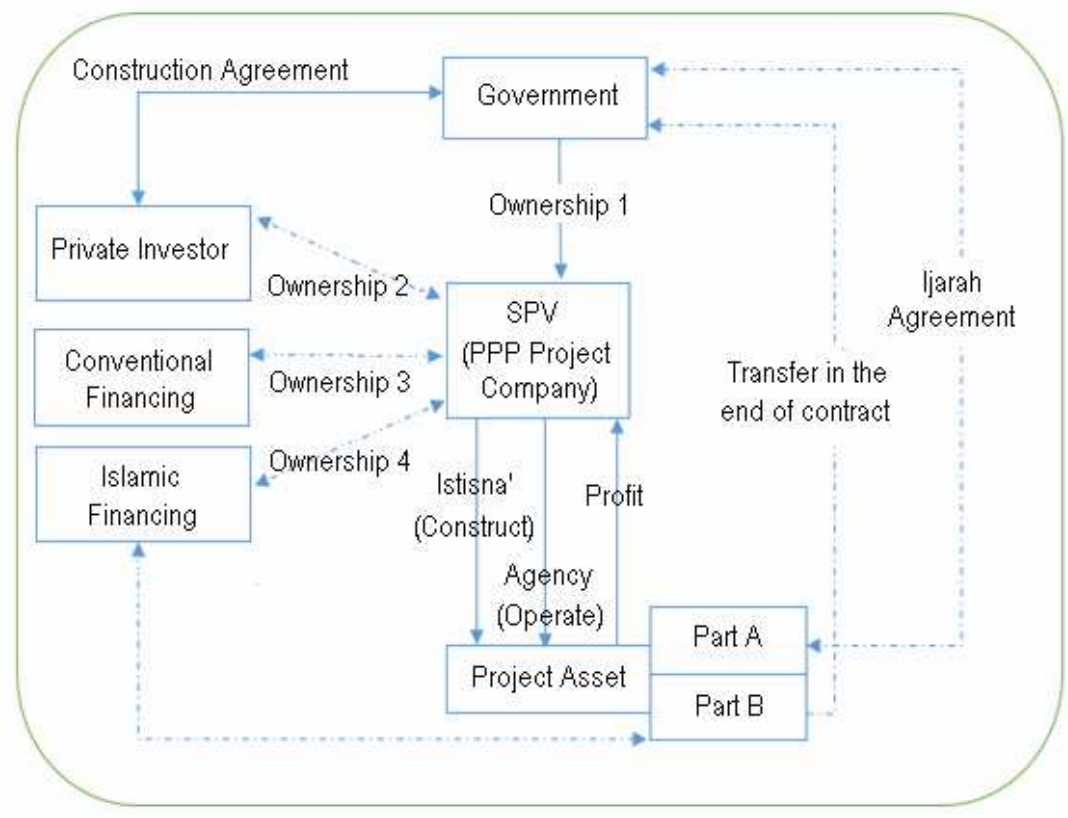

Source: Author's own

In Figure 4, based on the ownership based structure, during the concession period, the SPV is appointed as the agent to manage the project asset. Islamic financial institutions are flexible to use debt-based contracts such as Murabahah, Ijarah and Istisna or equity-based contracts such as Musharaka and Mudaraba to contribute the PPP project. This structure is based on profit and loss sharing principle, allowing conventional and Islamic financial institutes to hold a certain percentage of the ownership of the project assets, proportionate to the initial capital investment. At the end of the construction period, the government leases back not less than $50 \%$ to lead the project from the company. The profit generated both from the leasing payment from the government and the project operating period will be distributed based on the pre-agreed ratio to different investors. SPV here is getting the fee of managing the asset.

Unlike typical PPP models which have a contractual term between 20 and 30 years, this structure divides the project into part A and part B. By doing so, part A -- which requires larger part of financing -- can be leased back to the government in the early concession period (say 3-5 years of time), so that the investment recovery period of the enterprise can be shortened. Meanwhile, the profit generated could be relatively higher, which may help to reduce the financial pressure for parties involved. The part B asset will be transferred to government at the end of the concession period under agreed terms and conditions.

\section{Conclusion}

The BRI infrastructure construction covers a wide range sectors and often involves bilateral/multilateral cooperation with multiple stakeholders. Since the overall funding needs of BRI are so vast, the initiative requires multiple sources of funding to

International Journal of Management and Applied Research, Vol. 6, No. 1 
implement the project successfully. Countries participating along the BRI routes will continue to face funding and operational challenges; however, these challenges can be overcome if the financial institutes and policymakers enhance their multilateral cooperation, and create a level playing field and provide the infrastructure needed for further growth and development. A sound and functioning Islamic financial system could bridge the infrastructure gap for the countries involved.

This paper analysed few commonly used Islamic Finance contracts used in infrastructure financing and the characteristics of infrastructure project financing. Consistent with World Bank (2017), this paper found that Islamic finance can be well integrated together in mega infrastructure project. This paper also examined two Shariah-compliant projects. Based on a synthesis of existing literature, an enhanced PPP project model is proposed. The proposed model combines the use of conventional and Islamic finance, and divides a project into two phases. It will be of great benefit to conduct business cooperation and credit evaluation with Islamic financial system in the future. Another area requiring international collaborative efforts is the progressive harmonization of Shariah standards and practice.

Future research can examine the socio-economic implications of the Shariah-compliant project financing using quantitative research methods. Comparative studies on Shariah-compliant project financing in countries along BRI routes would be insightful.

\section{References}

1. Asian Infrastructure Investment Bank (AIIB) (2018), Financing Asia's Future: 2017 AIIB Annual Report and Financials, Beijing: Asian Infrastructure Investment Bank [Online] Available from: https://www.aiib.org/en/newsevents/news/2017/annual-report/common/pdf/AIIB-Annual-Report-2017.pdf [Accessed on 12 March 2018].

2. BankTrack (2016), Lower Sesan 2 dam Cambodia [Online] Available from: https://www.banktrack.org/project/lower_sesan_2_dam [Accessed on 2 March 2018].

3. Bilen, C. I. (2017), "YDA Group: taking a pioneering approach to project finance in Turkey", World Finance [Online] Available from:

https://www.worldfinance.com/infrastructure-investment/project-finance/ydagroup-taking-a-pioneering-approach-to-project-finance-in-turkey [Accessed on 12 March 2018].

4. Bing, L., Akintoye, A., Edwards, P.J. and Hardcastle, C. (2005), "The allocation of risk in PPP/PFI construction projects in the UK", International Journal of Project Management, Vol. 23, No. 1, pp. 25-35. https://doi.org/10.1016/j.ijproman.2004.04.006

5. Chandran, N. (2019) "Fears of excessive debt drive more countries to cut down their Belt and Road investments", $C N B C$ [Online] Available from: https://www.cnbc.com/2019/01/18/countries-are-reducing-belt-and-roadinvestments-over-financing-fears.html [Accessed on 12 March 2019].

International Journal of Management and Applied Research, Vol. 6, No. 1 
Belt and Road Initiative and Islamic Financing: The Case in Public Private Partnership Infrastructure Financing

6. Chan, N. H. (2018), "Myanmar successfully renegotiates debt, ownership terms for Kyaukphyu", Myanmar Times [Online] Available from:

https://www.mmtimes.com/news/myanmar-successfully-renegotiates-debtownership-terms-kyaukphyu.html [Accessed on 2 March 2019].

7. Chapra, M.U. (2011), “The global financial crisis: can Islamic finance help?”, In Islamic Economics and Finance, London: Palgrave Macmillan, pp. 135-142. https://doi.org/10.1057/9780230361133_5

8. Chen, M. (2016), "The Economic Adjustment of Saudi Arabia and the Docking of Bilateral Economy and Trade between China and Saudi Arabia under the One Belt and One Road Initiative", Journal of Middle Eastern and Islamic Studies (in Asia), Vol. 10, No. 2, pp. 46-70. https://doi.org/10.1080/19370679.2016.12023282

9. Central University of Finance and Economics (2018), Blue Book of PPP in China: China PPP Industry Development Report (2017-2018), China: Central University of Finance and Economics.

10. Combelo (2018), Pyra Power Plant [Online] Available from: https://www.compelo.com/energy/projects/payra-power-plant/ [Accessed on 12 March 2018].

11. Dawn (2015), \$1.5bn loan pacts signed for first Thar coal mining, power project [Online] Available from: https://www.dawn.com/news/1227907[Accessed on 12 March 2018].

12. Deloitte (2018), Embracing the BRI ecosystem in 2018, [Online] Available from: https://www2.deloitte.com/insights/us/en/economy/asia-pacific/china-belt-androad-initiative.html [Accessed on 12 March 2018].

13. Global Islamic Finance Report (2016), Islamic Project Finance: A Growing Trend, [Online] Available from: http://www.gifr.net/gifr2016/ch_08.pdf [Accessed on 12 March 2018].

14. Hao, Z. (2018), "China's top bank ICBC becomes biggest bond issuer on Nasdaq Dubai", Chinadaily [Online] Available from: http://www.chinadaily.com.cn/a/201803/07/WS5a9f5005a3106e7dcc1401ea.html [Accessed on 14 March 2019].

15. Huang, Y. (2016), “Understanding China's Belt \& Road initiative: motivation, framework and assessment", China Economic Review, Vol. 40, pp.314-321. https://doi.org/10.1016/j.chieco.2016.07.007

16. International Monetary Fund (IMF) (2010), IMF Survey: Islamic Banks: More Resilient to Crisis? [Online] Available from: https://www.imf.org/en/News/Articles/2015/09/28/04/53/sores100410a [Accessed on 14 March 2019].

17. International Rivers (2012), Comments to CF Carbon Fund II Ltd Regarding the Kamchay Hydropower Project (Cambodia) [Online] Available from: https://www.internationalrivers.org/resources/comments-to-cf-carbon-fund-ii-ltdregarding-the-kamchay-hydropower-project-cambodia-3059 [Accessed on 4 March 2019].

International Journal of Management and Applied Research, Vol. 6, No. 1 
Belt and Road Initiative and Islamic Financing: The Case in Public Private Partnership Infrastructure Financing

18. Islamic Corporation for The Development of the Private Sector (2011), China : Forging The Next Phase of Growth [Online] Available from: https://icdps.org/uploads/files/China\%20\%20Forging\%20the \%20Next\%20Phase \%20of\%20Growth\%20\%20March\%2020171528184711_6882.pdf [Accessed on 1 March 2019].

19. Kamel, M.S. (2018), "China's Belt and Road Initiative: Implications for the Middle East", Cambridge Review of International Affairs, Vol. 31, No. 1, pp.76-95. https://doi.org/10.1080/09557571.2018.1480592

20. Kana, G. (2017), "More Chinese companies to raise funds via sukuk?", The Star, [Online] Available from: https://www.thestar.com.my/business/businessnews/2017/07/28/more-chinese-companies-to-raise-funds-via-sukuk/ [Accessed on 14 March 2019].

21. Li, F. (2018), "The Role of Islam in the Development of the Belt and RoadInitiative", Asian Journal of Middle Eastern and Islamic Studies, Vol. 12, No. 1, pp.35-45. https://doi.org/10.1080/25765949.2018.1439617

22. Maasho, A. (2018), "UPDATE 1-Ethiopia PM says China will restructure railway loan", Reuters [Online] Available from: https://www.reuters.com/article/ethiopiachina-loan/update-1-ethiopia-pm-says-china-will-restructure-railway-loanidUSL5N1VS4IW [Accessed on 14 March 2019].

23. Mohieldin, M. (2012), Realizing the potential of Islamic finance, Washington DC: World Bank Group.

24. Organisation for Economic Cooperation and Development (OECD) (2017), Investing in Climate, Investing in Growth, Paris: OECD Publishing. http://dx.doi.org/10.1787/9789264273528-en

25. PPP Knowledge Lab (2017), PPP Reference Guide - Version 3, [Online] Available from: https://pppknowledgelab.org/guide/sections/1-introduction [Accessed on 12 March 2019].

26. PwC (2017), Repaving the ancient Silk Routes, [Online] Available from: https://www.pwc.com/gx/en/growth-markets-centre/assets/pdf/pwc-gmc-repavingthe-ancient-silk-routes-web-full.pdf [Accessed on 12 March 2019].

27. Rahmat, M. Z. (2019), The Rise of Islamic Finance on China's Belt and Road [Online] Available from: https://thediplomat.com/2019/02/the-rise-of-islamicfinance-on-chinas-belt-and-road/ [Accessed on 12 March 2019].

28. Selmier, W. T. (2018), "The Belt and Road Initiative and the influence of Islamic economies", Economic and Political Studies, Vol. 6, No. 3, pp.257-277. https://doi.org/10.1080/20954816.2018.1498989

29. Shepard, W. (2016), “The Story Behind The World's Emptiest International Airport", Forbes, [Online] Available from: https://www.forbes.com/sites/wadeshepard/2016/05/28/the-story-behind-theworlds-emptiest-international-airport-sri-lankas-mattala-rajapaksa/\#e9dbdfa7cea2 [Accessed on 1 March 2019].

International Journal of Management and Applied Research, Vol. 6, No. 1 
Belt and Road Initiative and Islamic Financing: The Case in Public Private Partnership Infrastructure Financing

30. Tan, B. (2018), The Belt and Road Initiative +Saudi Vision 2030, Jeddah: Chinese Consulate General [Online] Available from: http://jeddah.chinaconsulate.org/eng/xgxw/t1601404.htm [Accessed on 12 March 2018].

31. Wang, X. (2013), "Lack of Interest”, Global Times [Online] Available from: http://www.globaltimes.cn/content/798821.shtml [Accessed on 12 March 2019].

32. Woetzel, J.; Garemo, N.; Mischke, J.; Hjerpe, M. and Palter, R. (2016), Bridging Global Infrastructure Gaps. McKinsey \& Company, [Online] Available from: https://www.mckinsey.com/industries/capital-projects-and-infrastructure/ourinsights/bridging-infrastructure-gaps-has-the-world-made-progress [Accessed on 12 March 2019].

33. World Bank Group (2017), Mobilizing Islamic Finance for Infrastructure PublicPrivate Partnerships [Online] Available from: https://ppiaf.org/documents/5369/download [Accessed on 12 March 2019].

34. World Bank Group (2018), Procuring Infrastructure Public-Private Partnerships 2018 in China, [Online] Available from: https://bpp.worldbank.org/content/dam/documents/bpp/china.pdf [Accessed on 12 March 2019].

35. United Nations Economic Commission for Europe (UNECE) (2017), UNECE and China strengthen their cooperation on people first Public-Private Partnerships [Online] Available from: https://www.unece.org/info/media/presscurrent-pressh/ecid/2017/unece-and-china-strengthen-their-cooperation-on-people-first-publicprivate-partnerships/doc.html [Accessed on 12 March 2019].

36. Yang, J. (2018), Sachal 50MW Wind Farm Project: Special Report on CPEC Projects, Pakistan: Chinese Embassy [Online] Available from: https://pk.chineseembassy.org/eng/zbgx/CPEC/t1627098.htm [Accessed on 12 March 2019].

37. Zen, F. (2018), Public-Private Partnership Development in Southeast Asia. The Philipines: Asian Development Bank [Online] Available from: https://olc.worldbank.org/system/files/Bite\%2B\%201\%20Pages\%20from\%20ewp553-ppp-development-southeast-asia-2.pdf [Accessed on 12 March 2019].

International Journal of Management and Applied Research, Vol. 6, No. 1 